\title{
A Mini-Review on Non-Aqueous Lithium-Oxygen Batteries - Electrochemistry and Cathode Materials
}

\author{
Ahmer Riaz ${ }^{1,2}$, Kyu-Nam Jung ${ }^{1}$, and Jong-Won Lee ${ }^{1,2, *}$ \\ ${ }^{1}$ New and Renewable Energy Research Division, Korea Institute of Energy Research, 152 Gajeong-ro, Yuseong-gu, Daejeon \\ 305-343, Republic of Korea \\ ${ }^{2}$ Department of Advanced Energy Technology, Korea University of Science and Technology, 217 Gajeong-ro, Yuseong-gu, \\ Daejeon 305-350, Republic of Korea
}

\begin{abstract}
There is a great deal of current interest in the development of rechargeable batteries with high energy storage capability due to an increasing demand for electric vehicles (EVs) with driving ranges comparable to those of gasoline-powered vehicles. Among various types of batteries under development, a $\mathrm{Li}-\mathrm{O}_{2}$ battery delivers the highest theoretical energy density; thus, it is considered a promising energy storage technology for EV applications. Despite the fact that extensive research efforts have been made in the field of $\mathrm{Li}_{-} \mathrm{O}_{2}$ batteries in recent years, there are still many technical challenges to be addressed, such as low round-trip efficiency, poor reversibility, and poor power capability. In this article, we provide a short review on the fundamental electrochemistry of $\mathrm{Li}_{-} \mathrm{O}_{2}$ batteries with non-aqueous electrolytes and on electrode materials that have been employed in cathodes (oxygen electrodes). The major aim of this mini-review is to highlight the physical and electrochemical origins of scientific challenges facing $\mathrm{Li}-\mathrm{O}_{2}$ battery technology and to overview the strategies proposed to overcome them.
\end{abstract}

Keywords: Lithium-oxygen battery, Electrochemistry, Cathode, Carbon, Nanomaterial

Received March 29, 2015 : Accepted April 10, 2015

\section{Introduction}

World's total consumption of gasoline in 2010 was $\sim 89$ million barrels per day, out of which $\sim 22$ million barrels per day $(\sim 25 \%)$ were used to drive cars. This accounts for $\sim 2.8$ billion metric tons of $\mathrm{CO}_{2}$ emission only by vehicles running on the road [1]. In fact, transport sector is the second largest source of $\mathrm{CO}_{2}$ emissions, for instance, accounting for $\sim 32 \%$ of total U.S. $\mathrm{CO}_{2}$ emissions in 2012, [2] which leads to a significant amount of global warming (the earth's temper- atures are predicted to rise by $1.4-5.8^{\circ} \mathrm{C}$ by 2100) [3]. To address this environmental issue, there are a great deal of research activities to develop alternative methods for vehicular propulsion, e.g., electric vehicles. Batteries are an efficient electrochemical device to store electrical energy; however, current battery technologies such as lithium-ion batteries suffer from low energy storage capability [4,5]. To power the energy-hungry vehicles, therefore, a remarkable jump in energy density is urgently needed.

Since its commercialization, a Li-ion battery has

*Corresponding author. Tel.: +82-42-860-3025, Fax: +82-42-860-3297

E-mail address: jjong277@kier.re.kr

Open Access DOI: http://dx.doi.org/10.5229/JECST.2015.6.2.50

This is an Open Access article distributed under the terms of the Creative Commons Attribution Non-Commercial License (http://creativ ecommons.org/licenses/by-nc/3.0/) which permits unrestricted non-commercial use, distribution, and reproduction in any medium, provided the original work is properly cited. 
become the main stream power sources for portable electronic devices and hybrid/plug-in hybrid EVs [68]. However, the energy density of current Li-ion batteries is too low to realize long-range EVs, even under the assumption that the theoretical capacities of the electrode materials used can be fully utilized [7,9]. Li-ion batteries operate via the well-known intercalation and de-intercalation reactions, in which the crystal structures of the host materials are maintained. The amount of $\mathrm{Li}$, which can be stored by the intercalation reaction, is limited by the crystal structure of the electrode material. It is, therefore, essential to find new battery chemistries that can overcome the limit of today's Li-ion batteries.

A lithium-oxygen $\left(\mathrm{Li}-\mathrm{O}_{2}\right)$ battery, which couples a Li negative electrode (anode) and an $\mathrm{O}_{2}$ positive electrode (cathode), is able to offer very high energy density. The cell discharge reaction between $\mathrm{Li}$ and $\mathrm{O}_{2}$ to yield $\mathrm{Li}_{2} \mathrm{O}$ (reaction (1)) delivers a theoretical energy density of $5200 \mathrm{Wh} \mathrm{kg}^{-1}$ and, if discharged to $\mathrm{Li}_{2} \mathrm{O}_{2}$ (reaction (2)), a theoretical energy density of $3623 \mathrm{Wh} \mathrm{kg}^{-1}$ is achieved [7,10,11]:

$$
\begin{array}{ll}
4 \mathrm{Li}_{(\mathrm{s})}+\mathrm{O}_{2(\mathrm{~g})}=2 \mathrm{Li}_{2} \mathrm{O} & E^{\mathrm{o}}=2.91 \mathrm{~V} \text { vs. } \mathrm{Li} / \mathrm{Li}^{+} \\
2 \mathrm{Li}_{(\mathrm{s})}+\mathrm{O}_{2(\mathrm{~g})}=\mathrm{Li}_{2} \mathrm{O}_{2} & E^{\mathrm{o}}=2.96 \mathrm{~V} \text { vs. } \mathrm{Li} / \mathrm{Li}^{+}
\end{array}
$$

\section{Basic aspects of non-aqueous $\mathrm{Li}-\mathrm{O}_{2}$ batteries}

The concept of Li- $\mathrm{O}_{2}$ chemistry was first proposed in 1976 [12]; however, it received little attention until the rechargeability of a non-aqueous $\mathrm{Li}-\mathrm{O}_{2}$ battery was demonstrated by Abraham and Jiang in 1996 [13]. Fig. 1 describes the working principle of a non-aqueous Li$\mathrm{O}_{2}$ battery. A Li- $\mathrm{O}_{2}$ battery consists of a Li metal anode, a Li-ion conducting electrolyte, and a porous cathode that is usually made of carbon. During discharge, $\mathrm{Li}$ is oxidized to $\mathrm{Li}^{+}$, and the generated electron flows through the electric circuit towards the cathode. $\mathrm{Li}^{+}$migrates across the electrolyte to the cathode where oxygen $\left(\mathrm{O}_{2}\right)$ from the atmosphere is reduced and combines with $\mathrm{Li}^{+}$to form $\mathrm{Li}_{2} \mathrm{O}_{2}$ (reaction (2)). The reverse reaction occurs upon charge.

To develop a practical non-aqueous $\mathrm{Li}-\mathrm{O}_{2}$ battery, many daunting challenges are needed to be addressed. Dendrite formation during repeated $\mathrm{Li}$ dissolution-deposition cycles is a well-known problem [14]. Development of a Li metal anode that can be cycled safely and reversibly is required for long-

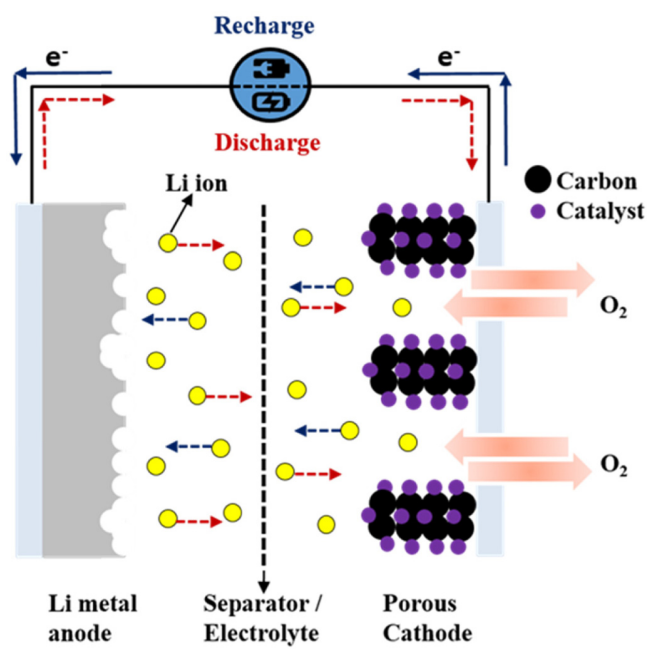

Fig. 1. Working principle of a non-aqueous $\mathrm{Li}^{-} \mathrm{O}_{2}$ battery.

term operation of the $\mathrm{Li}-\mathrm{O}_{2}$ battery. To find a stable non-aqueous electrolyte is one of the major challenges facing the $\mathrm{Li}-\mathrm{O}_{2}$ battery technology. The carbonate-based electrolytes, which have been commonly used for Li-ion batteries, are known to be unstable in contact with carbon electrodes and superoxide radical $\left(\mathrm{O}_{2}{ }^{-}\right)$generated during battery operation [15-17]. Other electrolytes based on ethers [18], sulfoxides [19], and ionic liquids [20] have been employed in $\mathrm{Li}-\mathrm{O}_{2}$ batteries so far; however, a truly stable electrolyte has not been demonstrated yet. A cathode is another key component of the Li- $\mathrm{O}_{2}$ battery as the main electrochemical reactions, i.e., oxygen reduction reaction (ORR) and oxygen evolution reaction (OER), occur at its surface. The cathode also accommodates the discharge product $\left(\mathrm{Li}_{2} \mathrm{O}_{2}\right)$ during battery operation. The cathode suffers from a lower-than-expected capacity as well as poor round-trip efficiency, rate-capability, and cyclability [21-25].

Due to the practical significance of a non-aqueous $\mathrm{Li}-\mathrm{O}_{2}$ battery system and the key importance of a cathode, the main focus of this review is on understanding the basic electrochemistry at the cathode as well as on exploring materials used as cathodes for non-aqueous $\mathrm{Li}-\mathrm{O}_{2}$ batteries. In the following sections, we describe the fundamental electrochemistry of a non-aqueous Li$\mathrm{O}_{2}$ battery, physicochemical properties of the discharge product $\left(\mathrm{Li}_{2} \mathrm{O}_{2}\right)$, and its impact on cell performance. Furthermore, we offer a brief review on carbon-based cathode materials used for $\mathrm{Li}_{2} \mathrm{O}_{2}$ batteries. 


\section{Electrochemistry of a non-aqueous $\mathrm{Li}-\mathrm{O}_{2}$ battery}

\subsection{Reaction mechanism}

Two possible electrochemical reactions for a $\mathrm{Li}-\mathrm{O}_{2}$ couple are described by Eqs. (1) and (2). Since there is no sound experimental evidence of $\mathrm{Li}_{2} \mathrm{O}$ production during discharge according to various analyses such as nuclear magnetic resonance (NMR) spectroscopy [26], X-ray diffractometry (XRD) [27], and Xray photoelectron spectroscopy (XPS) [28], $\mathrm{Li}_{2} \mathrm{O}_{2}$ formation/decomposition (reaction (2)) is believed to be the prevailing reaction during $\mathrm{Li}-\mathrm{O}_{2}$ battery operation. This is also favorable because the decomposition of $\mathrm{Li}_{2} \mathrm{O}$ would not be reversible [29]. Moreover, a recent computational study by Radin et al. [30] showed that the stable $\mathrm{Li}_{2} \mathrm{O}_{2}$ surfaces exhibit a halfmetallic property, while those of $\mathrm{Li}_{2} \mathrm{O}$ are non-metallic, and as a result, $\mathrm{Li}_{2} \mathrm{O}_{2}$ would become the main discharge product of the $\mathrm{Li}-\mathrm{O}_{2}$ battery.

Cyclic voltammetry (CV) [31-34] has been employed on different electrodes and electrolytes to define the reaction mechanism of the $\mathrm{Li}-\mathrm{O}_{2}$ battery. In the $\mathrm{CV}$ measurements, an $\mathrm{O}_{2}$ reduction part of the $\mathrm{CV}$ curve is equivalent to battery discharging, and the oxidation part is equivalent to charging. $\mathrm{CV}$ was first employed by Laoire et al. [31,32] to describe the ORR/OER mechanism of $\mathrm{Li}^{-} \mathrm{O}_{2}$ electrochemistry in a non-aqueous electrolyte using a glassy carbon electrode and various electrolyte salts and solvents. The observed $\mathrm{O}_{2}$ reduction and oxidation peaks were explained based on the electrochemical and chemical reactions described in Eqs. (3)-(6) [31-35]:

$$
\begin{aligned}
& 2 \mathrm{Li}=2\left(\mathrm{Li}^{+}+\mathrm{e}^{-}\right) \\
& \mathrm{Li}^{+}+\mathrm{e}^{-}+\mathrm{O}_{2} \text { (ads) }=\mathrm{LiO}_{2} \text { (ads) } \\
& \mathrm{Li}^{+}+\mathrm{e}^{-}+\mathrm{LiO}_{2} \text { (ads) }=\mathrm{Li}_{2} \mathrm{O}_{2} \text { (ads) } \\
& \mathrm{LiO}_{2} \text { (ads) }+\mathrm{LiO}_{2} \text { (ads) }=\mathrm{Li}_{2} \mathrm{O}_{2} \text { (ads) }+\mathrm{O}_{2}
\end{aligned}
$$

As the discharge product species, $\mathrm{Li}_{2} \mathrm{O}_{2}$, has no solubility in most of the non-aqueous electrolytes, reactions (4)-(6) involve ion and electron transfer across the surface of the adsorbed species. Since large toroids of $\mathrm{Li}_{2} \mathrm{O}_{2}$ have often been observed, reaction (7) involving a "solution"-based route for the formation of $\mathrm{Li}_{2} \mathrm{O}_{2}$ has been proposed to justify their existence [36]:

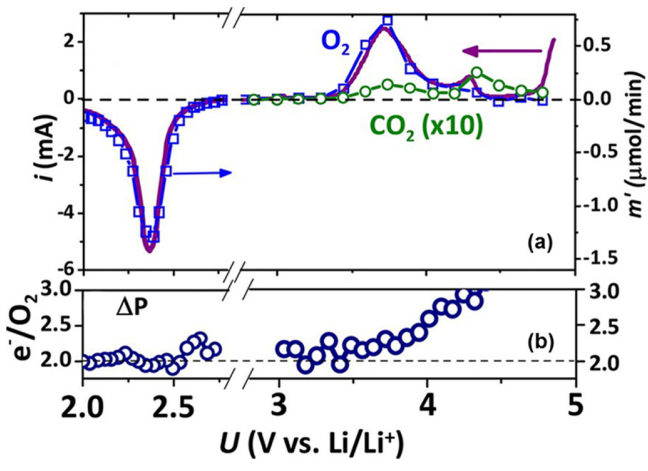

Fig. 2. (a) Linear sweep voltammetry measured at $0.5 \mathrm{mV}$ $\mathrm{s}^{-1}$ and (b) the number of electrons transferred per mole of $\mathrm{O}_{2}$ determined by the DEMS cell with an XC72 carbon cathode and $1 \mathrm{M}$ LiTFSI-DME electrolyte. Reprinted from McCloskey et al. [34], Copyright (C2012 with permission from American Chemical Society.

$$
\mathrm{LiO}_{2}+\mathrm{LiO}_{2} \rightarrow \mathrm{Li}_{2} \mathrm{O}_{2}+\mathrm{O}_{2} \rightarrow \mathrm{Li}_{2} \mathrm{O}_{2} \text { (ads) }+\mathrm{O}_{2}
$$

Peng et al. [33] combined CV with surfaceenhanced Raman spectroscopy on a roughened $\mathrm{Au}$ electrode to examine the species formed during the ORR and OER. They provided direct evidence of $\mathrm{LiO}_{2}$ as an intermediate species during the ORR, which then disproportionates to $\mathrm{Li}_{2} \mathrm{O}_{2}$. The authors concluded that reaction (6) is more dominant than reaction (5). The absence of $\mathrm{LiO}_{2}$ on the OER indicated that $\mathrm{Li}_{2} \mathrm{O}_{2}$ decomposes directly to evolve $\mathrm{O}_{2}$ by reaction (8) and does not pass through $\mathrm{LiO}_{2}$ as an intermediate:

$$
\mathrm{Li}_{2} \mathrm{O}_{2} \rightarrow 2\left(\mathrm{Li}^{+}+\mathrm{e}^{-}\right)+\mathrm{O}_{2}
$$

McCloskey et al. [34] employed differential electrochemical mass spectroscopy (DEMS) along with $\mathrm{CV}$ in a LiTFSI-DME electrolyte. As shown in Fig. 2 , the calculated number of electrons transferred per mole of $\mathrm{O}_{2}$ consumed (ORR) or evolved (OER) was $\sim 2$. This suggests that there is no evidence for 1 electron/mole of $\mathrm{O}_{2}$ process forming $\mathrm{LiO}_{2}$ or a 4 electrons/mole of $\mathrm{O}_{2}$ process forming $\mathrm{Li}_{2} \mathrm{O}$, which confirms $\mathrm{Li}_{2} \mathrm{O}_{2}$ as the major discharge product.

\subsection{Physicochemical properties of discharge products and their impact on electrochemical behaviors}

A unique aspect of $\mathrm{Li}-\mathrm{O}_{2}$ electrochemistry is the deposition of the discharge product $\left(\mathrm{Li}_{2} \mathrm{O}_{2}\right)$ on the 
surface of the cathode. The deposited discharge product, which is insoluble and has bulk insulating electrical properties, plays a critical role in determining battery performance, such as the overpotentials and capacity during discharging and charging, and cyclability [37]. Electrochemical reactions during battery cycling would predominantly take place on the surface of deposited $\mathrm{Li}_{2} \mathrm{O}_{2}$ rather than on the electrode surface. Therefore, many researchers have focused their attention to study the mechanism of discharge product formation [36,38-40] and its effects on the charging behavior of the Li- $\mathrm{O}_{2}$ battery $[36,41,42]$. In particular, the rate-dependent morphologies of the deposited discharge product have been theoretically predicted [43] and experimentally observed $[36,38,39]$. Adams et al. [36] observed the formation of large toroids of $\mathrm{Li}_{2} \mathrm{O}_{2}$ at a low current density of $5 \mu \mathrm{A} \mathrm{cm}{ }^{-2}$ but the formation of film-like deposits at $100 \mu \mathrm{A} \mathrm{cm}^{-2}$ (Fig. 3). They suggested that the preceding discharge pathway has a crucial influence on the subsequent OER reaction. $\mathrm{Li}_{2} \mathrm{O}_{2}$ films consisting of small particles formed at high discharge rates leads to lower charge overpotentials, i.e., improved roundtrip efficiency.
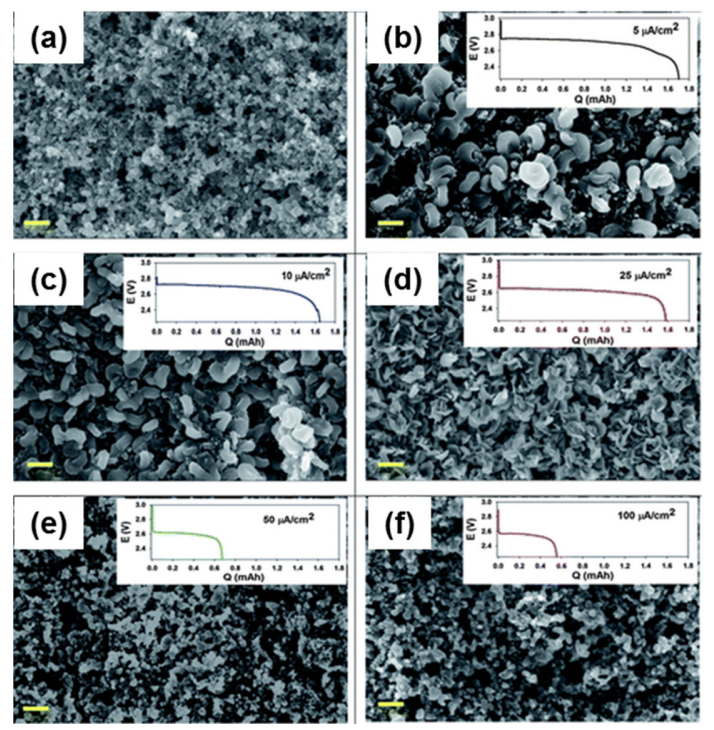

Fig. 3. SEM images and the corresponding discharge curves for (a) the pristine cathode and (b-f) the cathodes discharged at various current densities: (b) $5 \mu \mathrm{A} \mathrm{cm}^{-2}$; (c) $10 \mu \mathrm{A} \mathrm{cm}-2$; (d) $25 \mu \mathrm{A} \mathrm{cm}^{-2}$; (e) $50 \mu \mathrm{A} \mathrm{cm}^{-2}$; (f) $100 \mu \mathrm{A} \mathrm{cm}^{-2}$. Scale bar $=400 \mathrm{~nm}$. Reprinted from Adams et al. [36], Copyright (C2013 with permission from The Royal Society of Chemistry.
Mitchell et al. [39] probed the mechanistic details of $\mathrm{Li}_{2} \mathrm{O}_{2}$ formation using ex-situ scanning electron microscopy (SEM) and transmission electron microscopy (TEM) analyses of discharged CNT electrodes. At lower rates, $\mathrm{Li}_{2} \mathrm{O}_{2}$ particles were initially formed as stacked thin plates with thicknesses of $\sim 10 \mathrm{~nm}$, and then, the plates splayed out, followed by additional plate nucleation, which caused the formation of toroidal $\mathrm{Li}_{2} \mathrm{O}_{2}$ particles. The TEM analysis confirmed that toroid particles are highly crystalline with the $\mathrm{Li}_{2} \mathrm{O}_{2}(0001)$ facet normal to the axis of the toroid. The average crystallite sizes of electrochemically formed $\mathrm{Li}_{2} \mathrm{O}_{2}$ have been measured to be approximately 10$15 \mathrm{~nm}[36,39,42]$. Moreover, computational studies by Radin et al. [30] and by Mo et al. [44] have suggested that (0001) is the predominant surface in the equilibrium Wulff construction of $\mathrm{Li}_{2} \mathrm{O}_{2}$ crystallites. Stoichiometric $\mathrm{Li}_{2} \mathrm{O}_{2}$ displays an insulating characteristics having a band gap of $1.88 \mathrm{eV}$ [45]; however, $\mathrm{Li}_{2} \mathrm{O}_{2}$ surfaces can be conductive in the presence of $\mathrm{LiO}_{2}$-like species (with Li vacancies) formed as intermediates during the discharge process.

In general, a Li- $\mathrm{O}_{2}$ battery exhibits slight overpotentials during discharging; on the other hand, charge overpotentials are substantially high. The charge process turned out to consist of two different reactions: one with low overpotentials at the surface, followed by a bulk oxidation process with higher overpotentials, as proposed by Lu et al. [41]. The low overpotential process corresponds to surface delithiation (reaction (5)), followed by disproportionation (reaction (6)). Bulk oxidation (reaction (8)) is suggested to show higher overpotentials. In a later work, Gallant et al. [42] studied the effect of $\mathrm{Li}_{2} \mathrm{O}_{2}$ morphologies

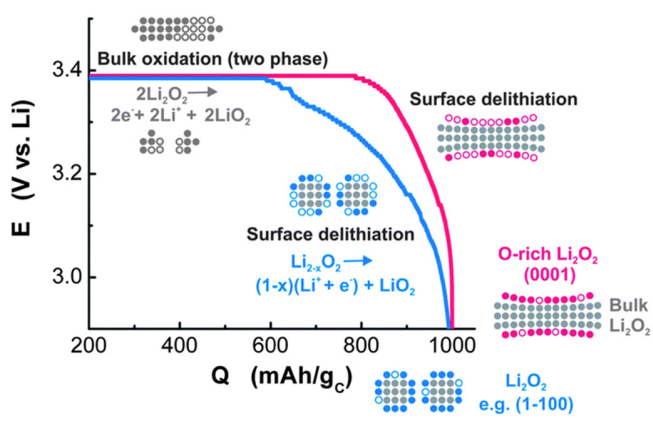

Fig. 4. Charging processes of $\mathrm{Li}_{2} \mathrm{O}_{2}$ with disk or particle morphologies. Reprinted from Gallant et al. [42], Copyright (C2013 with permission from The Royal Society of Chemistry. 
on the charging behavior. As shown in Fig. 4, the authors employed a potentiostatic intermittent titration technique (PITT) to distinguish between lowand high-overpotential regions during charging of disk- and particle-like $\mathrm{Li}_{2} \mathrm{O}_{2}$. They proposed that relatively small particles exhibit a slower rise in charge overpotentials as compared to large toroidal particles, which is attributed to a larger surface-to-volume ratio (i.e., a larger fraction of the surface delithiation with lower overpotentials).

\section{Carbon-based cathodes for $\mathrm{Li}-\mathrm{O}_{2}$ batteries}

The insoluble nature of the discharge products in non-aqueous $\mathrm{Li}_{-} \mathrm{O}_{2}$ batteries makes the cathode design quite complicated. The surface of a porous cathode is passivated due to the accumulation of nonconductive solid $\mathrm{Li}_{2} \mathrm{O}_{2}$ species [37], and the pathways of reactants such as $\mathrm{Li}^{+}$and $\mathrm{O}_{2}$ are blocked by $\mathrm{Li}_{2} \mathrm{O}_{2}$, resulting in increased cell resistances [46-48]. Performance of the cathode does not solely depend upon either the surface area, pore volume, or pore size of the cathode; instead, it is governed by an interplay of these parameters [49]. The cathodes for $\mathrm{Li}-\mathrm{O}_{2}$ batteries should be able to $(i)$ transport reactant species efficiently; (ii) provide a three-phase region (electrolyte/cathode/oxygen) for electrochemical reactions; and (iii) store a large amount of the discharge product. The three-dimensional (3D) architecture of the cathode plays a significant role in battery performance. Carbon has been widely employed as a cathode material for non-aqueous $\mathrm{Li}-\mathrm{O}_{2}$ batteries owing to its advantages over other materials, such as low cost, high conductivity, high pore volume, large surface area, low weight, and easy fabrication.

\section{1. $\mathrm{Li}_{2} \mathrm{O}_{2}$ storage in porous carbon cathodes}

As mentioned above, carbon is the cathode material of choice for non-aqueous $\mathrm{Li}-\mathrm{O}_{2}$ batteries under development because of its unique properties. In this section, we review the previous works on carbonbased cathode materials with special emphasis to their physical properties (e.g., surface area and porosity) and their role in $\mathrm{Li}^{-} \mathrm{O}_{2}$ battery performance. Yang et al. [50] synthesized a mesocellular carbon foam (MCF-C) using a mesocellular foam (MCF) silica hard template. The prepared carbon cathode showed a bimodal pore size distribution centered at $\sim 4.3$ and $\sim 30.4 \mathrm{~nm}$. As compared to conventional carbon black, MCF-C could store a larger amount of $\mathrm{Li}_{2} \mathrm{O}_{2}$ within its mesopores, as revealed by the TEM analysis (Fig. 5(a)). Large pore volumes and mesopore sizes allowed for the deposition of more $\mathrm{Li}_{2} \mathrm{O}_{2}$ during discharging, thereby enhancing electrochemical performance. Mirzaeian and Hall [51] prepared porous activated carbons through a polycondensation process and compared the carbons with different porous structures. Their results suggested that the $\mathrm{Li}-\mathrm{O}_{2}$ battery performance is simultaneously determined by carbon's pore volume, pore size, and surface area.

Fig. 5(b) shows a model for the passivation of a cathode surface by $\mathrm{Li}_{2} \mathrm{O}_{2}$ precipitation proposed by Tran et al. [46]. The majority of solid $\mathrm{Li}_{2} \mathrm{O}_{2}$ would be formed inside the micro-, meso-, and macro-pores in carbon. As shown in the enlarged inset of Fig. 5(b), $\mathrm{Li}_{2} \mathrm{O}_{2}$ particles formed near the orifices of micropores would block mass transfer in and out of those pores, resulting in premature death of the cathode. These results suggest that a dual pore system for carbon would be beneficial for enhancing the $\mathrm{Li}-\mathrm{O}_{2}$ battery performance: micro-pores can be used for
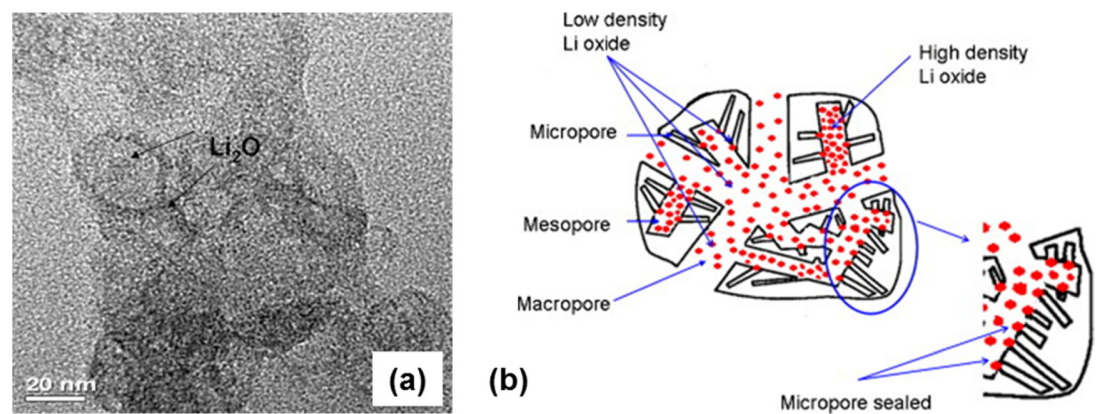

Fig. 5. (a) TEM image of $\mathrm{Li}_{2} \mathrm{O}_{2}$ deposits in pores of mesocellular carbon foam after discharge at $0.1 \mathrm{~mA} \mathrm{~cm}{ }^{-2}$. Reprinted from Yang et al. [50], Copyright (C2009 with permission from Elsevier B.V. (b) Schematic diagram of $\mathrm{Li}_{2} \mathrm{O}_{2}$ storage in carbon with various pores. Reprinted from Tran et al. [46], Copyright (C2009 with permission from Elsevier B.V. 
transport of oxygen without blockage by the discharge product, and meso- and macro-pores can be mainly used to accommodate the discharge product. Using this design concept, Xiao et al. [52], Guo et al. [53], and Wang et al. [54] have prepared functionalized graphene sheets, mesoporous/ macroporous carbon sphere arrays, and carbon aerogel with a dual pore system, respectively. The dual pore system is able to facilitate oxygen diffusion in two independent pore channels, while providing open spaces for $\mathrm{Li}_{2} \mathrm{O}_{2}$ storage, thus creating a suitable triple-phase reaction zone. This leads to a higher discharge capacity and improved rate-capability of the battery.

\subsection{Carbon cathodes for $\mathrm{Li}_{-} \mathrm{O}_{2}$ batteries}

One-dimensional (1D) carbon structures, such as carbon nanotubes (CNT) and carbon nanofibers (CNFs), have high surface areas, conductivity, and catalytic activity; thus, they are considered promising cathode materials for $\mathrm{Li}-\mathrm{O}_{2}$ batteries [55]. Low carbon packing in CNF electrodes and high utilization of the available carbon mass and void volume for $\mathrm{Li}_{2} \mathrm{O}_{2}$ formation result in a high specific discharge capacity, as reported by Mitchell et al. [24]. Some treatments of CNTs, which can induce active edge sites and modify pore size distributions, can enhance Li$\mathrm{O}_{2}$ battery performance. For example, Li et al. [56] found that partially cracked CNTs (1513 $\mathrm{mAh} \mathrm{g}^{-1}$ ) led to the two-fold improvement in the capacity compared with non-cracked CNTs $\left(800 \mathrm{mAh} \mathrm{g}^{-1}\right)$. Mi et al. [57] achieved a significant increase in the capac-
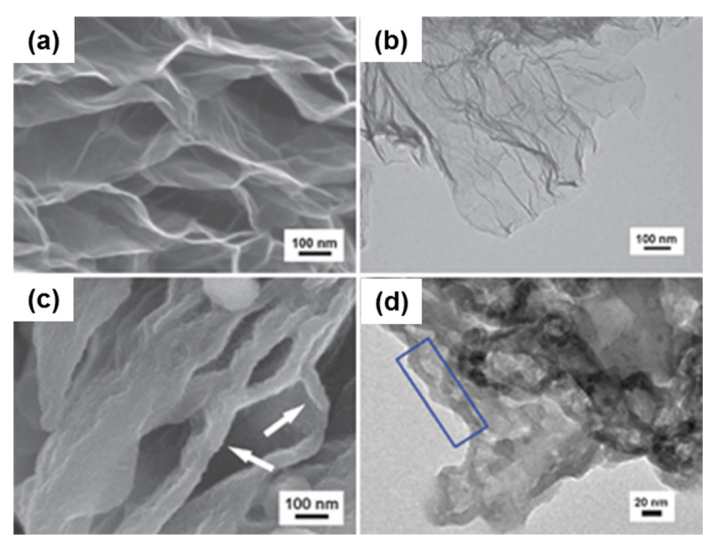

Fig. 6. (a, c) SEM and (b, d) TEM images of the (a, b) pristine and (c, d) discharged GNS electrodes. Reprinted from Li et al. [60], Copyright (C2011 with permission from The Royal Society of Chemistry. ity, using nitrogen-doped CNTs, which was ascribed to uniform distribution of the discharge product. Lim et al. [58] prepared a hierarchical fibril carbon electrode by orthogonally organizing aligned CNT sheets. This electrode structure promoted mass transport in the open framework, which led to a uniform deposition of the discharge products on individual CNTs, and hence, it showed stable cyclability with a $1000 \mathrm{mAh} \mathrm{g}^{-1}$ capacity for 70 cycles.

Two-dimensional (2D) graphene materials have excellent electrical conductivity as well as high specific surface areas and remarkable mechanical strengths [59]. Graphene nanosheets (GNSs) exfoliated from graphite on a large scale are populated with edge sites and defects. The edge and defect sites on the GNS surface are known to serve as active sites for electrochemical reactions (ORR and OER) [59]. In fact, Li et al. [60] demonstrated that GNSs showed a much higher discharge capacity $\left(8706 \mathrm{mAh} \mathrm{g}^{-1}\right)$ than other forms of carbon such as BP-200 (1909 $\mathrm{mAh} \mathrm{g}^{-1}$ ) and Vulcan XC-72 (1054 $\left.\mathrm{mAh} \mathrm{g}^{-1}\right)$. As shown in Fig. 6 , the GNSs have a curly morphology with a thin, wrinkled structure. Such a unique structure would enable efficient electrolyte wetting and oxygen diffusion, thus improving the cathode performance. Also, 3D graphene-based cathodes have been designed; for instance, Xiao et al. [52] prepared a 3D hierarchically porous cathode using functionalized 2D GNSs. The cathode fabricated in their work contained interconnected pore channels on both micro- and nanometer length scales and delivered a capacity as high as $15000 \mathrm{mAh} \mathrm{g}^{-1}$. The authors combined experiments with DFT calculations and found that defects and functional groups on graphene are able to facilitate the formation of isolated nano-sized $\mathrm{Li}_{2} \mathrm{O}_{2}$ particles and to help prevent electrode blocking.

\subsection{Catalytic materials incorporated into carbon- based cathodes}

Carbon as a cathode material has reasonable ORR activity; however, it exhibits relatively low activity for the OER. Although it is still debatable whether high overpotentials for charge is due to low OER catalytic activity of carbon or is the result of carbon decomposition [61], several researchers have used additional catalysts to enhance the OER kinetics. A true catalytic effect, in principle, should lower a discharge-charge voltage gap and improve rate-capability; however, it remains unclear whether a catalyst 
would indeed improve the overall performance, because it is observed in some studies that catalyst actually catalyzes the electrolyte decomposition, rather than promoting the $\mathrm{Li}_{2} \mathrm{O}_{2}$ decomposition [61].

The ORR catalytic activity trends of various metals in a non-aqueous electrolyte were reported by $\mathrm{Lu} e t$ al. [62]. The non-aqueous ORR activity was found to be dependent upon relative oxygen adsorption energy on different metal surfaces. The OER catalytic effect of $\mathrm{Pd}$ nanoparticles on $\mathrm{Al}_{2} \mathrm{O}_{3}$-coated carbon was reported by Lu et al. [63]. A significant decrease in the charging potential was observed with Pd nanoparticles $\left(\sim 3.2 \mathrm{~V} v\right.$ s. $\left.\mathrm{Li} / \mathrm{Li}^{+}\right)$, which the authors attributed to the combined effects of the followings (Fig. 7): (i) catalytic effect of Pd nanoparticles; (ii) a nano-crystalline form of $\mathrm{Li}_{2} \mathrm{O}_{2}$; and (iii) $\mathrm{Al}_{2} \mathrm{O}_{3}$ coating preventing electrolyte decomposition on carbon. Fan et al. [64] studied the influence of Au nanoparticles anchored on CNTs. Au nanoparticles anchored to vertically aligned CNTs provided additional nucleation sites for $\mathrm{Li}_{2} \mathrm{O}_{2}$, leading to the decreased size while increasing the density of $\mathrm{Li}_{2} \mathrm{O}_{2}$ particles during the discharge process. Upon charge, the Au nanoparticles acted as a promoter for the decomposition of $\mathrm{Li}_{2} \mathrm{O}_{2}$. Moreover, the Au nanoparticles showed a promoting effect on the decomposition of carbonate species arising from the side reactions. These effects consequently led to the reduced charge overpotentials and extended cycle operation of the batteries. Various metal-carbon composite materials have been demonstrated to improve the ORR in the $\mathrm{Li}-\mathrm{O}_{2}$ batteries [65-67]; however, as these studies have not reported the OER activity, the role of metals in improving the

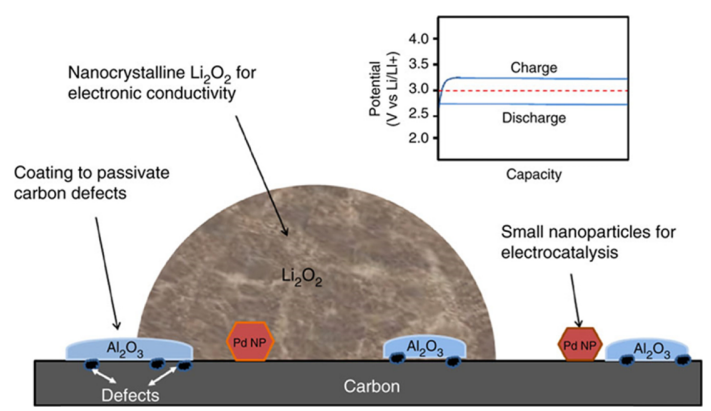

Fig. 7. Schematic diagram of a cathode made of $\mathrm{Al}_{2} \mathrm{O}_{3}$ coating and $\mathrm{Pd}$ nanocatalysts. The inset shows the chargedischarge performance of the $\mathrm{Li}-\mathrm{O}_{2}$ battery. Reprinted from Lu et al. [63], Copyright (C2013 with permission from Macmillan Publishers Ltd. cathode performance as compared to only carbon remains unclear.

Metal oxides have been widely used as catalysts in Li- $\mathrm{O}_{2}$ batteries due to their lower cost compared to precious metals. Among various metal oxides, $\mathrm{MnO}_{2}$ has received much attention. The catalytic effect of $\mathrm{MnO}_{2}$ is dependent on its crystallographic structure and morphology. Truong et al. [68] synthesized $\delta-$ $\mathrm{MnO}_{2}$ microflowers, $\alpha-\mathrm{MnO}_{2}$ nanowires, and $\alpha-$ $\mathrm{MnO}_{2}$ nanotubes by microwave-assisted hydrothermal reduction of potassium permanganate in the presence of hydrochloric acid. The single crystal $\alpha-$ $\mathrm{MnO}_{2}$ nanotubes showed improved catalytic activity toward the electrochemical processes involved in the Li- $\mathrm{O}_{2}$ cells, due to high crystallinity and unique morphologies with high surface areas. Qin et al. [69] prepared uniformly dispersed $\alpha-\mathrm{MnO}_{2}$ nanoparticles on carbon and demonstrated that the $\mathrm{Li}^{-} \mathrm{O}_{2}$ battery exhibited a high discharge capacity of $\sim 1400 \mathrm{mAh} \mathrm{g}^{-1}$ and a low charge potential of $\sim 3.5 \mathrm{~V} v s . \mathrm{Li} / \mathrm{Li}^{+}$in a TEGDME electrolyte. Black et al. [70] demonstrated that the charge overpotential could be significantly reduced when a nanocrystalline $\mathrm{Co}_{3} \mathrm{O}_{4} / \mathrm{RGO}$ composite was incorporated into the carbon-based cathode. They claimed that $\mathrm{Co}_{3} \mathrm{O}_{4} / \mathrm{RGO}$ clearly enhances the kinetics of mass or surface transport for both the ORR and OER rather than conventional electrocatalytic effects of the particles. Perovskite oxides have high electronic/ionic conductivity and catalytic activity and are thus considered suitable catalytic materials for $\mathrm{Li}^{-\mathrm{O}_{2}}$ batteries. Xu et al. [71] prepared $\mathrm{La}_{0.75} \mathrm{Sr}_{0.25} \mathrm{MnO}_{3}$ (LSM) nanotubes by an electrospinning technique combined with post-heattreatment. When used with carbon, LSM significantly reduced the OER overpotentials and thus improved the round-trip efficiency of the battery.

\section{Concluding remarks}

There is no doubt that a non-aqueous $\mathrm{Li}-\mathrm{O}_{2}$ battery represents a promising energy storage system with high energy density that can enable long-range EVs in the future. However, the technology is still immature, and a lot of technical challenges must be addressed to develop commercial products, including low round-trip efficiency and poor cyclability. Recently, the instability of carbon as a cathode material was identified to be a major set-back in the development of Li- $\mathrm{O}_{2}$ batteries. Several studies [72-76] 
have indicated that, in addition to electrolyte decomposition, the reaction of carbon with $\mathrm{Li}_{2} \mathrm{O}_{2}$ is the main source of $\mathrm{Li}_{2} \mathrm{CO}_{3}$ formation on the carbon surface, which in turn increases charge overpotentials and reduce cyclability. Some progress has been made in this field by employing non-carbon materials as the cathodes [77-79]. Furthermore, the stability of electrolyte depends on the nature of the cathode materials used and vice versa; therefore, it is required to find out the stable electrolyte-cathode couples rather than looking at individual components.

\section{Acknowledgement}

This work was supported by an Energy Efficiency \& Resources Core Technology Program of the Korea Institute of Energy Technology Evaluation and Planning (KETEP) granted from the Ministry of Trade, Industry \& Energy, Republic of Korea. (no. 20112020100110/KIER B5-2592).

\section{References}

[1] The U.S. Energy Information Administration (EIA) (http://www.eia.gov).

[2] United Stated Environmental Protection Agencey (http:// www.epa.gov).

[3] LiveScience (http://www.livescience.com).

[4] Z. Yang, J. Zhang, M.C.W. Kintner-Meyer, X. Lu, D. Choi, J.P. Lemmon, J. Liu, Chem. Rev., 111, 3577(2011).

[5] P.G. Bruce, S.A. Freunberger, L.J. Hardwick, J.-M. Tarascon, Nat. Mater., 11, 19(2012).

[6] R. Huggins, Advance Batteries: Material Science Aspect, Springer, New York (2009).

[7] B. Scrosati, K.M. Abraham, W. van Schalkwijk, J. Hassoun, Lithium Batteries: Advanced Technologies and Applications, John Wiley \& Sons Inc., New Jersey (2013).

[8] J. Lu, L. Li, J.-B. Park, Y.-K. Sun, F. Wu, K. Amine, Chem. Rev., 114, 5611(2014).

[9] G. Girishkumar, B. McCloskey, A.C. Luntz, S. Swanson, W. Wilcke, J. Phys. Chem. Lett., 1, 2193(2010).

[10] Y. Lu, B.M. Gallant, D.G. Kwabi, J.R. Harding, R.R. Mitchell, M. Stanley, Y. Shao-Horn, Energy Environ. Sci., 6, 750(2013).

[11] J. Christensen, P. Albertus, R.S. Sanchez-Carrera, T. Lohmann, B. Kozinsky, R. Liedtke, J. Ahmed, A. Kojic, J. Electrochem. Soc., 159, R1(2012).

[12] D.N. Bennion and E.L. Littauer, J. Electrochem. Soc., 123, 1462(1976).

[13] K.M. Abraham, Z. Jiang, J. Electrochem. Soc., 143, 1(1996).

[14] I. Yoshimatsu, T. Hirai, J. Yamaki, J. Electrochem. Soc., 135, 2422(1988).
[15] S.A. Freunberger, Y. Chen, Z. Peng, J.M. Griffin, L.J. Hardwick, F. Bardé, P. Novák and P.G. Bruce, J. Am. Chem. Soc., 133, 8040(2011).

[16] B.D. McCloskey, D.S. Bethune, R.M. Shelby, G. Girishkumar, A.C. Luntz, J. Phys. Chem. Lett., 2, 1161(2011).

[17] L. Grande, E. Paillard, J. Hassoun, J. Park, Y. Lee, Y. Sun, S. Passerini, B. Scrosati, Adv. Mater, 27, 784(2015).

[18] J. Read, J. Electrochem. Soc., 153, A96(2006).

[19] D. Xu, Z. Wang, J. Xu, L. Zhang, X. Zhang, Chem. Commun., 48, 6948(2012).

[20] T. Kuboki, T. Okuyama, T. Ohsaki, N. Takami, J. Power Sources, 146, 766(2005).

[21] K. Mizushima, P.C. Jones, P.J. Wiseman, J.B. Goodenough, Mater. Res. Bull., 15, 783(1980).

[22] F.T. Wagner, B. Lakshmanan, M.F. Mathias, J. Phys. Chem. Lett., 1, 2204(2010).

[23] Y. Zhang, C.-Y. Wang, J. Electrochem. Soc., 156, A527(2009).

[24] R.R. Mitchell, B.M. Gallant, C.V. Thompson, Y. ShaoHorn, Energy Environ. Sci., 4, 2952(2011).

[25] H.-G. Jung, J. Hassoun, J.-B. Park, Y.-K. Sun, B. Scrosati, Nat. Chem., 4, 579(2012).

[26] M. Leskes, N.E. Drewett, L.J. Hardwick, P.G. Bruce, G.R. Goward, C.P. Grey, Angew. Chemie. Int. Ed., 51, 8560(2012).

[27] R. Black, S.H. Oh, J.-H. Lee, T. Yim, B. Adams, L.F. Nazar, J. Am. Chem. Soc., 134, 2902(2012).

[28] R. Younesi, S. Urbonaite, K. Edström, M. Hahlin, $J$. Phys. Chem. C, 116, 20673(2012).

[29] W. Xu, K. Xu, V.V. Viswanathan, S.A. Towne, J.S. Hardy, J. Xiao, Z. Nie, D. Hu, D. Wang, J.-G. Zhang, J. Power Sources, 196, 9631(2011).

[30] M.D. Radin, J.F. Rodriguez, F. Tian, D.J. Siegel, J. Am. Chem. Soc., 134, 1093(2011).

[31] C.O. Laoire, S. Mukerjee, K.M. Abraham, E.J. Plichta, M.A. Hendrickson, J. Phys. Chem. C, 113, 20127(2009).

[32] C.O. Laoire, S. Mukerjee, K.M. Abraham, E.J. Plichta, M.A. Hendrickson, J. Phys. Chem. C, 114, 9178(2010).

[33] Z. Peng, S.A. Freunberger, L.J. Hardwick, Y. Chen, V. Giordani, F. Bardé, P. Novák, D. Graham, J.M. Tarascon, P.G. Bruce, Angew. Chemie. Int. Ed., 50, 6351(2011)

[34] B.D. McCloskey, R. Scheffler, A. Speidel, G. Girishkumar, A.C. Luntz, J. Phys. Chem. C, 116, 23897(2012).

[35] J.S. Hummelshøj, A.C. Luntz, J.K. Nørskov, J. Chem. Phys., 138, 034703(2013).

[36] B.D. Adams, C. Radtke, R. Black, M.L. Trudeau, K. Zaghib, L.F. Nazar, Energy Environ. Sci., 6, 1772(2013).

[37] M. Radin, F. Tian, D. Siegel, J. Mater. Sci., 47, 7564(2012).

[38] L. Zhong, R.R. Mitchell, Y. Liu, B.M. Gallant, C.V. Thompson, J.Y. Huang, S.X. Mao, Y. Shao-Horn, Nano Lett., 13, 2209(2013). 
[39] R.R. Mitchell, B.M. Gallant, Y. Shao-Horn, C.V. Thompson, J. Phys. Chem. Lett., 4, 1060(2013).

[40] D. Zhai, H.-H. Wang, J. Yang, K.C. Lau, K. Li, K. Amine, L.A. Curtiss, J. Am. Chem. Soc., 135, 15364(2013).

[41] Y.-C. Lu, Y. Shao-Horn, J. Phys. Chem. Lett., 4, 93(2012).

[42] B.M. Gallant, D.G. Kwabi, R.R. Mitchell, J. Zhou, C.V. Thompson, Y. Shao-Horn, Energy Environ. Sci., 6, 2518(2013).

[43] B. Horstmann, B. Gallant, R. Mitchell, W.G. Bessler, Y. Shao-Horn, M.Z. Bazant, J. Phys. Chem. Lett., 4, 4217(2013).

[44] Y. Mo, S.P. Ong, G. Ceder, Phys. Rev. B, 84, 205446(2011).

[45] J.S. Hummelshøj, J. Blomqvist, S. Datta, T. Vegge, J. Rossmeisl, K.S. Thygesen, A.C. Luntz, K.W. Jacobsen, J.K. Nørskov, J. Chem. Phys., 132, 071101(2010).

[46] C. Tran, X.-Q. Yang, D. Qu, J. Power Sources, 195, 2057(2010).

[47] M. Mirzaeian, P.J. Hall, J. Power Sources, 195, 6817(2010).

[48] M. Eswaran, N. Munichandraiah, L.G. Scanlon, Electrochem. Solid-State Lett., 13, A121(2010).

[49] R. Black, B. Adams, L.F. Nazar, Adv. Energy Mater, 2, 801(2012).

[50] X. Yang, P. He, Y. Xia, Electrochem. Commun., 11, 1127(2009).

[51] M. Mirzaeian, P.J. Hall, Electrochem. Acta, 54, 7444(2009).

[52] J. Xiao, D. Mei, X. Li, W. Xu, D. Wang, G.L. Graff, W.D. Bennett, Z. Nie, L.V. Saraf, I.A. Aksay, J. Liu, J.G. Zhang, Nano Lett., 11, 5071(2011).

[53] Z. Guo, D. Zhou, X. Dong, Z. Qiu, Y. Wang, Y. Xia, Adv. Mater, 25, 5668(2013).

[54] F. Wang, Y.-H. Xu, Z.-K. Luo, Y. Pang, Q.-X. Wu, C.-S. Liang, J. Chen, D. Liu, X. Zhang, J. Power Sources, 272, 1061(2014).

[55] R. H. Baughman, A.A. Zakhidov, W.A. de Heer, Science, 297, 787(2002).

[56] J. Li, B. Peng, G. Zhou, Z. Zhang, Y. Lai, M. Jia, ECS Electrochem. Lett., 2, A25(2013).

[57] R. Mi, H. Liu, H. Wang, K.-W. Wong, J. Mei, Y. Chen, W.-M. Lau and H. Yan, Carbon, 67, 744(2014).

[58] H.D. Lim, K.Y. Park, H. Song, E.Y. Jang, H. Gwon, J. Kim, Y.H. Kim, M.D. Lim, R.O. Robles, X. Leprõ, R.H. Baughman, K. Kang, Adv. Mater, 25, 1348(2013).

[59] A. Ambrosi, C.K. Chua, A. Bonanni, M. Pumera, Chem. Rev., 114, 7150(2014).

[60] Y. Li, J. Wang, X. Li, D. Geng, R. Li, X. Sun, Chem.
Commun., 47, 9438(2011).

[61] B.D. McCloskey, R. Scheffler, A. Speidel, D.S. Bethune, R.M. Shelby, A.C. Luntz, J. Am. Chem. Soc., 133, 18038(2011).

[62] Y.C. Lu, H.A. Gasteiger, Y. Shao-Horn, J. Am. Chem. Soc., 133, 19048(2011).

[63] J. Lu, Y. Lei, K.C. Lau, X. Luo, P. Du, J. Wen, R.S. Assary, U. Das, D.J. Miller, J.W. Elam, H.M. Albishri, D.A. El-Hady, Y.-K. Sun, L.A. Curtiss, K. Amine, Nat. Commun., 4, 2383(2013).

[64] W. Fan, X. Guo, D. Xiao, L. Gu, J. Phys. Chem. C, 118, 7344(2014)

[65] Y. Shen, D. Sun, L. Yu, W. Zhang, Y. Shang, H. Tang, J. Wu, A. Cao, Y. Huang, Carbon, 62, 288(2013).

[66] Y. Yang, M. Shi, Q.-F. Zhou, Y.-S. Li, Z.-W. Fu, Electrochem. Commun., 20, 11(2012).

[67] X. Ren, S.S. Zhang, D.T. Tran, J. Read, J. Mater. Chem., 21, 10118(2011).

[68] T.T. Truong, Y. Liu, Y. Ren, L. Trahey, Y. Sun, $A C S$ Nano, 6, 8067(2012).

[69] Y. Qin, J. Lu, P. Du, Z. Chen, Y. Ren, T. Wu, J.T. Miller, J. Wen, D.J. Miller, Z. Zhang, K. Amine, Energy Environ. Sci., 6, 519(2013).

[70] R. Black, J.H. Lee, B. Adams, C.A. Mims, L.F. Nazar, Angew. Chemie. Int. Ed., 52, 392(2013).

[71] J.J. Xu, D. Xu, Z.L. Wang, H.G. Wang, L.L. Zhang, X.B. Zhang, Angew. Chemie. Int. Ed., 52, 3887(2013).

[72] B.D. McCloskey, A. Speidel, R. Scheffler, D.C. Miller, V. Viswanathan, J.S. Hummelshøj, J.K. Nørskov, A.C. Luntz, J. Phys. Chem. Lett., 3, 997(2012).

[73] B.M. Gallant, R.R. Mitchell, D.G. Kwabi, J. Zhou, L. Zuin, C.V. Thompson, Y. Shao-Horn, J. Phys. Chem. C, 116, 20800(2012)

[74] W. Xu, J. Hu, M.H. Engelhard, S.A. Towne, J.S. Hardy, J. Xiao, J. Feng, M.Y. Hu, J. Zhang, F. Ding, M.E. Gross, J.-G. Zhang, J. Power Sources, 215, 240(2012).

[75] M.M. Ottakam Thotiyl, S.A. Freunberger, Z. Peng, P.G. Bruce, J. Am. Chem. Soc., 135, 494(2012).

[76] B.D. McCloskey, A. Valery, A.C. Luntz, S.R. Gowda, G.M. Wallraff, J.M. Garcia, T. Mori, L.E. Krupp, $J$. Phys. Chem. Lett., 4, 2989(2013).

[77] Z. Peng, S.A. Freunberger, Y. Chen, P.G. Bruce, Science, 337, 563(2012).

[78] A. Riaz, K.-N. Jung, W. Chang, S.-B. Lee, T.-H. Lim, S.-J. Park, R.-H. Song, S. Yoon, K.-H. Shin, J.-W. Lee, Chem. Commun., 49, 5984(2013).

[79] A. Riaz, K.-N. Jung, W. Chang, K.-H. Shin, J.-W. Lee, ACS Appl. Mater. Interfaces, 6, 17815(2014). 